\title{
A Research on Customer Loyalty Based on the Network Marketing
}

\author{
Wenhua Qiu \\ Jiangxi University of Finance and Economics, Nanchang, China \\ chwh26@sohu.com
}

\begin{abstract}
For a long time, the formation and maintenance of customer loyalty have always been one of the key points of the traditional marketing and network marketing. With the rapid development of market economy in China, the domestic market is also more open and international. The network marketing entered the Chinese market with its strong practicality and resource recovery. People's shopping behavior extends from the traditional physical store to the virtual shop on the network. But there is no doubt that no matter the traditional physical store, or a virtual store, which conforms to the trend of the Times, the obtaining and maintenance of customer loyalty is always the key to obtain maximized benefit.

Based on the summary and analysis of related theory and influence factors about network marketing and customer loyalty, this article analyzed emphatically how to effectively maintain the customer loyalty under the condition of network marketing; and to some extent, explained the formation mechanism of customer loyalty under the condition of the network.
\end{abstract} factor

Keywords-Network marketing; Customer loyalty;Influencing

\section{INTRODUCTION}

Until December 2014, there are 649 million Internet users in China, a total of 31.17 million Internet users were created throughout the year. Internet penetration rate is $47.9 \%$, increased by $2.1 \%$ than the end of 2013 . ${ }^{[1]}$

Compared the fast growth of Internet shopping and group purchase business applications, there is still room for the enterprise electronic commerce application to improve. Online shopping websites have already become the most popular shopping search platform for internet users. In recent years, due to the rise of large shopping platform, on the platform, goods category are enriched; information are more complete; the prices are also very competitive. Internet users are more willing to directly search on these shopping platform.

All of these show the fierce competition under the condition of the network. But the competition between the enterprises is not a product or service competition, but competition for customers. This means that those who win the customers win the victory. And obtaining the customer is not the key to win, but how to retain customers. The goal of enterprises should be forming customer loyalty rather than customer satisfaction itself.

\section{THE FORMATION MECHANISM OF CUSTOMER LOYALTY UNDER THE CONDITION OF NETWORK MARKETING}

\section{A. The Concept and Advantage of Network Marketing}

According to the new definition given by American marketing association (AMA) in 2004, marketing is an organized function to create, communicate and transmit value for customers, and to realize the interest of the organization and the stakeholders ${ }^{[2]}$. Network marketing is based on Internet media, and it uses new methods and ideas to implement marketing activities. It can more effectively create, communicate and transmit value to realize the interests of the organization and stakeholders. Due to its low cost and fast speed, the Internet led the rapid development of network marketing. And the most important thing is the information exchange. This is also the difference from the traditional marketing. The network marketing's advantages lie in:

(1) The traditional marketing has a strong time limitation. No market is to provide service for 24 hours. At the same time it also sets a limitation for us to buy goods in other countries. However, Network marketing can help everyone enjoy the global service anytime and anywhere.

(2) One of the most significant features of the network market is virtuality. In the network market, the information release of enterprise, the information receipt of customer and the commodity trading process are all conducted online. The media of marketing information is digital text, images, sound, etc. Network virtualization of the market helps information communication between the sellers and buyers. When the seller shows their products to the buyer actively, the buyer also claims the information needed from the seller and feedback their information.

In the traditional shopping environment, the completion of a trading fastest takes a few minutes, the slowest requires a few hours. Of course, the journey time is not included .Sometimes people can't get products they want even looking for a day. But in the network shopping environment, people can see a lot of store information and commodity information in a minute ${ }^{[3]}$. When you find desirable product, you can easily click the mouse and complete the shopping. This saves a lot of time and energy and improves the shopping efficiency.

(3) Low cost of network operation makes the price a major advantage. Network marketing saves enterprises huge promotion fee and circulation cost. All of these make the price become a major advantage. Online sellers can operate at home or warehouse, this decreases a lot of 
cost. If you want to buy the product, you can search globally to find the most preferential price. You can also order directly from the manufacturer.

(4) Compared with the traditional marketing, network marketing is more personalized; it pays more attention to the needs of the customers. In network marketing, the enterprise can actively communicate with customers and understand their needs, so as to design or to provide more products to meet their requirements. The customers' active participation helps them independently choose products they like, which makes the marketing more personalized.

\section{B. The Concept and Formation of Customer Loyalty}

Customer loyalty means the customers show a strong emotional specificity, and priority-selection behavior for particular goods and services as well as the providing companies. Loyal customers repeat purchasing or consume a certain brand products; they may also recommend this brand product to their friends and relatives. Simply speaking, it is the behavior of repeating purchase and driving others' participation.

\section{The Importance of Customer Loyalty under the Network Condition}

Study on customer retention and customer profitability relationship: a 5\% increase in customer loyalty helps corporate profits increase by $25 \%$ to $85 \%$. Either under traditional marketing or network marketing conditions, the focus of enterprise are from "product center" into "customer center", the customer is gradually become dominant in business. Under the condition of the network marketing the importance of customer loyalty to the enterprise is mainly manifested in:

1) Improve corporate profits

In the network shopping environment, the consumer is no longer simply to accept the goods provided by the seller, instead, they are more of a predominates. So the longer loyal customers buy the more corporate profits. At the same time, they are not too sensitive to price because they trust it. The corporate needn't waste unnecessary costs.

\section{2) Cost reduction of the enterprise}

If a new customer is not familiar with the website and processes, the enterprise has to spend much more time and money to provide more services [4]. But loyal customers know this well, which make staff have more time and energy to receive new customers; the management efficiency is also improved. The enterprise competitive ability is also promoted. Patrons pay higher prices than new customers actually; sometimes the promotion discount applies only to new customers.

\section{3) The effect of word of mouth}

Loyal customers' purchases are more targeted; they don't easily change the familiar website. They also have a better understanding of the various characteristics of the product. When his friends want to buy similar goods, he will initiatively recommend familiar website and products. The recommended customers are more valuable. By the word of mouth effect, the enterprise visibility is greatly strengthened.

\section{4) The overall value of the enterprise}

A loyal customer, can not only cause good reputation but also form one of the core competitiveness. A customer retained by Enterprise can bring immeasurable benefit. It is an incentive to enterprise employees, making them more believe the enterprise business strategy and better serve other customers confidently.

\section{THE INFLUENCE FACTORS OF CUSTOMER LOYALTY}

\section{A. The Main Factors Influencing the Network Consumers' Purchases}

1) Product features

Consumers on the network are mainly composed of young people in our country, they accept new things faster, like the pursuit of self, the pursuit of fashion, the demand is becoming more and more unique, personalization is becoming more and more obvious, the popularization of products have been unable to interest them.

\section{2) The product price}

Network is transparent; consumers can get to know the price through comparing several websites or ask others. There are some special websites helping you save money. The network can help you know which seller offers the lowest price. A businessman doesn't play a leading role in price setting. Instead, the network consumers control more. Price is one of the factors considered when consumer buys a product.

\section{3) The convenience of shopping}

One of the reasons why Network consumers choose online shopping is the convenience and fast speed. Network consumers can find goods they want on the Internet anytime.

\section{4) The safety and reliability}

The network is virtual, you can't see the goods the seller when you shop. This is very difficult for most consumers to do network shopping. Many websites considered this, such as TaoBao, set up the third party AliPay, when you buy goods, put money into AliPay, after you received the goods, AliPay will transmit the money to the seller. Jingdong and Dangdang support cash on delivery, and these no doubtfully increased the network consumers' trust, and also make online shopping more safe and reliable.

\section{B. The Influencing Factors of Customer Loyalty}

\section{1) Customer satisfaction}

Customer satisfaction is "buyer's cognitive status on whether they get enough returns from its pay in specific cases”. Simply speaking, it is the proportion of the product and the expectation. If the customer satisfaction degree is high, so the possibility of his next-time buy increases. This means that the customer's loyalty will improve with the improvement of customer satisfaction.

\section{2) Switching costs}

The study found that when the brand loyal customer wants to convert or change the brand, he needs to pay more time and money. Unless he can't find the products he needs. Because of his personal information and shopping habits, combined with his good understanding of website 
shopping process, if changing to other websites, he needs to spend more time and energy to constantly adapt to the new shopping environment. Although customer dominated in the network environment, but loyal customers go into a specific enterprise unceasingly, his conversion cost increases.

\section{3) The relationship trust}

The communication between customers and enterprises and the buying depend on his trust on the product or enterprise. People have no sense to network, they initial purchase only relies on commodity information provided by the enterprises and other buyers ${ }^{[5]}$. Then they decide whether or not for the second time to buy according to the feeling of first buying. Customers are more likely to have a sense of trust on the higher credit shop. So relationship trust is one of the factors that affect customer loyalty.

4) Product experiences

The quality of the product and the style of the product itself is one of the factors that affect customer loyalty. Loyal customers for the product know better than new customers; they are able to quickly find information about the product they need from past purchases experience and the understanding of the site.

5) The benefit correlation

First of all, in terms of products, it is customers' dependence on the products. For companies, the higher the dependence on the product, the higher the customers' loyalty is. From the customer's point of view, it is what kind of discount or service the enterprise can bring to him. When companies do some promotional activities regularly, or offer the members some certain preferential policies, Not only enterprise sales are improved, but the customer loyalty is also improved.

\section{6) Alternative choice}

When customers find substitute goods or better service, the possibility he turns to other businesses will be greatly enhanced. If the product is irreplaceable or other service cannot go beyond the service, customer loyalty will greatly improve. This requires businesses to create unique products, at the same time, to provide more quality services.

\section{THE STRATEGY TO MAINTAIN CUSTOMER LOYALTY UNDER THE CONDITION OF NETWORK MARKETING}

\section{A. The Establishment of the Online Customers' Loyalty}

\section{1) Establish a database for target customers}

In the network environment, all Internet users could be potential customers. What companies need to do is to find the target customers from potential customers. There are a lot of ways to obtain the information of the potential customers. For example, Internet users registering a website will leave personal information, email subscription information, and so on. Companies can also collect information through the more popular software, like micro blogging, WeChat. And what enterprises have to do is to establish a database and take some incentive measures.

2) Do personalized marketing

First, Internet marketing strategy need to satisfy the needs of customers, and personalized marketing can increase web site hits and purchase rate. Most of the buyers are the targeted customers; this not only can quickly build the relationship with the customer, but also can increase customer loyalty. This requires companies to understand and meet customer's various demands, meanwhile, cut costs as much as possible.

3) Update the website

Website is the first impression of consumers on an enterprise, so the design and contents of the website are particularly important. If the website design is interesting or the contents are of interest to consumers, then it can quickly attract the attention of consumers. Consumers are willing to stop and focus on it; it also requires that there are more contents of the website for customers to see. Website update means more interactive .Only the customer involved, the ability to purchase will greatly improve.

4) Establish a communication platform

The Establishment of consumer communication platform allows them to quickly generate a sense of belonging, through their constant communications about buying information and post-purchase evaluation, enterprises can learn more useful information, know more demand, and get more people involved. This undoubtedly increases emotional ties with customers, as well as the loyalty to the site and the enterprise so as to create more profits for the enterprise.

\section{B. The Maintenance of Network Customer Loyalty}

\section{1) To establish trust of the customer}

Doing online shopping, the customer is unable to see the goods itself, nor measure the value of goods. He can determine whether to buy or not only by pictures, audio, video and the evaluation of other buyers. The first of customer loyalty is to trust companies. The establishment of trust depends on various efforts. Most Internet users value most about a transaction security and privacy. Only to provide customers with a safe shopping environment, customers can increase the trust on the enterprise and website ${ }^{[6]}$.

\section{2) Strengthen brand awareness}

When we want to buy home appliance and electronic products on line, we think of Jingdong

Mall first. When we want to buy books online, the first thought is Amazon and Dangdang. This means that the brand awareness can bring us more customers. The increase of core competitiveness for enterprises is to constantly strengthen their own brand awareness, and then the loyal customers will be more loyal to the enterprise, at the same time the enterprises can have more new customers.

3) The satisfaction with service quality

Studies shown that customer satisfaction is one of the main factors influencing the customer loyalty. The important role cannot be denied. There are many ways to satisfy the customers. But the most important is satisfactory service quality. That not only includes the quality of products. The most important of website design is the service attitude of the personnel and fast shopping environment. So let the loyal customers feel he is respected, the service, as always, satisfy him. As a result, improving 
the service of enterprises is the key to improve customer loyalty.

\section{4) Complete membership system}

Designing more perfect Membership system, creating more effective promotion methods and improving the customer switching cost, are beneficial to the development of the customer loyalty and increase the repeat purchase ${ }^{[7]}$. The enterprises can invite some customers to participate in interactive according to their purchase amount, or award those who recommend others to buy, etc. If customers can get points or reward, the probability of their regular visit will be greatly enhanced. Customers may also impulse buying many products he doesn't need. It also provides customer loyalty with a good platform. Unified management of customer loyalty, and then according to the data analysis, regular mail to contact loyal customers, so as to strengthen their loyalty.

\section{CONCLUSION}

This article mainly discusses the relationship between the customer satisfaction, relationship trust, switching costs and customer loyalty and customer future behavior intention. In the real consumption environment, factors that affect customer satisfaction and customer loyalty are very complicated, such as the enterprise market image, customer perceived value, etc., and some scholars subdivide switching costs into procedural switching costs, financial switching costs and relational switching costs, therefore the results of the study are subjected to certain restrictions. In addition, the researches of customer loyalty under the condition of network have deep theoretical basis, due to the author's limited ability, the issues discussed here may have inevitable shortcomings, sincerely hope readers to point out mistakes.

\section{REFERENCES}

[1] Jaeoby, Chestnut.Performace outcomes of Purchasing arrangements in industrial buyer-vendor relationships, Junral of Marketing, 1990, pp.80-93

[2] Moormna Christine, Gerald Zaltman and Rohit Deshpande, relationships between Providers and Users of Marketing Research: The Dynamics of Trust within and between organizations. Journal of Marketing Reseach, 1992, 29(August): pp.314-329.

[3] Morgna, R.M. and Hunt, S.D.: The Commitment-Trust Theory of Relationship Marketing, 1994, pp. 20-38.

[4] Diek\&Basu, Customer loyalty: Toward na Integrated Framework. Journal of the Academy of science1994, pp.99-113

[5] Zhigang Si, Xiaojin Pu, "Network Marketing” Beijing, Mechanic Industry Press, 2005

[6] Changhong Bai, Yorozu, "A research on customer loyalty and its determinants of the service enterprises" ( $\mathrm{J}$ )

[7] Philip. Koteler, "marketing management: analysis, planning, implementation and control” (M), Shanghai, Shanghai people's publishing house, 1999 